\title{
RESEARCH
}

Open Access

\section{Oleic acid inhibits lung Na/K-ATPase in mice and induces injury with lipid body formation in leukocytes and eicosanoid production}

Cassiano Felippe Gonçalves-de-Albuquerque ${ }^{1 *}$, Patrícia Burth², Adriana Ribeiro Silva', Isabel Matos Medeiros de Moraes ${ }^{1}$, Flora Magno de Jesus Oliveira' ${ }^{1}$, Ricardo Erthal Santelli ${ }^{3}$, Aline Soares Freire ${ }^{3}$, Patrícia Torres Bozza', Mauricio Younes-lbrahim', Hugo Caire de Castro-Faria-Neto ${ }^{1}$

and Mauro Velho de Castro-Faria ${ }^{4}$

\begin{abstract}
Background: Acute respiratory distress syndrome (ARDS) can emerge from certain pathologies, such as sepsis, fat embolism and leptospirosis, in which the levels of unesterified fatty acids are increased in the patient's plasma. ARDS is characterized by edema formation, and edema resolution occurs mainly due to the pneumocyte Na/K-ATPase activity. As previously described, increased oleic acid (OA) plasma concentrations induce lung injury by interfering with sodium transport. The first aim of this study was to develop a radioactivity-free assay to detect Na,K-ATPase activity ex vivo using a model of OA-induced lung injury in mice. We also investigated the relationship between Na/K-ATPase inhibition and OA-induced lung injury using ouabain-induced lung injury as a comparison, because of the well-described effect of ouabain as a $\mathrm{Na} / \mathrm{K}$-ATPase inhibitor.
\end{abstract}

Methods: We developed a $\mathrm{Na} / \mathrm{K}$-ATPase assay based on the capture of non-radioactive $\mathrm{Rb}^{+}$ions by mice lung tissue in the absence or presence of ouabain, a specific $\mathrm{Na} / \mathrm{K}$-ATPase inhibitor. $\mathrm{Rb}^{+}$incorporation into the lung was measured by inductively coupled plasma-optical emission spectrometry (ICP-OES) after lung tissue mineralization. Na/K-ATPase activity was considered as the difference between $\mathrm{Rb}^{+}$incorporation in the absence and in the presence of ouabain. Bronchoalveolar lavage fluid was collected for lung injury assessment. For this assessment, cell counting, lipid body enumeration and lipid mediator concentrations were measured. Histological analyses were used to determinate lung pathology. Whole body plethysmographic analysis was performed to assay lung function.

Results: The lung Na/K-ATPase activity of mice was completely inhibited by an OA dose of 10 umol, an effect also obtained with $10^{-3} \mathrm{\mu mol}$ of ouabain, as demonstrated by the decreased $\mathrm{Rb}^{+}$incorporation in the lungs. The same $\mathrm{OA}$ dose induced lung edema and inflammation with cell influx, lipid body formation, and leukotriene $B_{4}\left(L_{T B}\right)$ and prostaglandin $E_{2}\left(P_{G} E_{2}\right)$ production. Ouabain also induced lung inflammation, as detected by histological examinations. As far as we know, this is the first time that ouabain-induced lung injury was shown. Both OA and ouabain induced functional lung pathology in mice simultaneously with inhibition of the lung Na/K-ATPase activity.

Conclusions: We developed a new non-radioactive assay to quantified Na/K-ATPase in vivo. OA and ouabain inhibited in vivo $\mathrm{Na}$ /K-ATPase activity in the lungs and induced lung injury. Our data reinforce the idea that Na/K-ATPase inhibitors may worsen lung injury in specific pathological conditions.

Keywords: Oleic acid, Na/K-ATPase, Lung, Lipid body, PGE2, LTB 4

\footnotetext{
* Correspondence: cassianofg@gmail.com

${ }^{1}$ Instituto Oswaldo Cruz, Laboratório de Imunofarmacologia, Fiocruz, Rio de Janeiro, RJ, Brazil

Full list of author information is available at the end of the article
} 


\section{Background}

The first description of adult respiratory distress syndrome (ARDS) appeared in 1967 [1]. A less severe form of ARDS is characterized by increased alveolus permeability [2]; however, according to the Berlin definition, the term ALI is no longer used, and ARDS can be stratified into mild, moderate and severe [3]. Further improvements in the Berlin definition have already been proposed [4]. The initial lesion in ARDS is an increase in the alveolar capillary permeability to plasma proteins, which leads to an interstitial and alveolar edema [3,5]. The resolution of pulmonary edema and of lung inflammation is a relevant factor for ARDS outcome [6]. Fluid management is one of the most important measures that has been shown to impact ARDS, and a dynamic monitoring of the lung fluid balance seems to influence clinical outcomes [7]. The removal of an alveolar edema depends on the vectorial transport of salt and water across the alveolar epithelium, in part through apically located sodium channels $(\mathrm{ENaC})$, followed by its extrusion into the lung interstitium via the basolaterally located $\mathrm{Na} / \mathrm{K}$-ATPase [8-10], which in turn drives the passive water flow toward the capillary net through certain transcellular channels, the aquaporins [10]. Thus, the direct epithelial cell injury and/or defects in ion transport inflicted by bacterial and viral pathogens or by oxidative injury lead to a reduction in fluid clearance [11].

The acute inflammatory response in ARDS compromises the integrity of the alveolar-capillary membrane. In this respect, OA can induce lung pathology that is similar to clinical ARDS [12].

In the present work, we developed a $\mathrm{Na} / \mathrm{K}$-ATPase assay based on non-radioactive $\mathrm{Rb}^{+}$uptake by mouse lung tissue $30 \mathrm{~min}$ after an intravenous (i.v.) injection of $\mathrm{OA}$, in the presence or absence of ouabain. In addition, we used an in vivo mouse model of ARDS induced by OA to evaluate edema formation, lung inflammation, and lung pathology that could result from $\mathrm{Na} / \mathrm{K}$-ATPase inhibition.

\section{Methods}

\section{Animals}

All experiments were conducted in male Swiss mice (25 - 35 g) obtained from the Oswaldo Cruz Foundation breeding unit. The animals were lodged at $22^{\circ} \mathrm{C}$ with a $12 \mathrm{~h}$ light/dark cycle and free access to food and water. Animal housing conditions and all experimental procedures conformed to institutional regulations and were in accordance with the National Institute of Health guidelines on animal care. The institutional animal welfare committee approved all of the procedures described here under license number 002-08.

\section{Preparation of oleate solutions}

OA (Sigma-Aldrich, St. Louis, MO) was used to prepare a $100 \mathrm{mM}$ tris-oleate solution as described in Gonçalves de Albuquerque, 2012 [13]. Briefly, after weighting and water addition, sodium hydroxide was slowly added until the $\mathrm{pH}$ reached 12.0. The mixture was sonicated to complete oleate solubility, and then, the $\mathrm{pH}$ was carefully adjusted to 7.6 with dilute Hydrochloric acid. The working oleate solutions were prepared by appropriate dilutions of the $100 \mathrm{mM}$ solution with sterile saline (PBS) $\mathrm{pH}$ 7.5. The working oleate solutions were tested for the presence of LPS by the limulus amebocyte lysate test (LAL), which was provided by the Instituto Nacional de Controle de Qualidade em Saúde (INCQS)-Fundação Oswaldo Cruz, and showed negative results.

\section{Intravenous administration of oleate}

Intravenous injections were administered into the orbital plexus (inner angle of the eye ball). Each group received $100 \mu \mathrm{L}$ of tris-oleate solution containing either 2.5, 5.0 or $10.0 \mu \mathrm{mol}$ of OA per animal. Edema formation and inflammatory parameters were measured several times after the challenge. Control groups received $100 \mu \mathrm{L}$ of sterile saline (PBS).

\section{$\mathrm{Na} / \mathrm{K}$ ATPase assay in mouse lungs based on $\mathrm{Rb}^{+}$incorporation}

The mice were divided into 3 groups and anesthetized with isoflurane. Each animal in the first group received $100 \mu \mathrm{L}$ of a $\mathrm{KCl}$ free-Hank's solution containing $8 \mu \mathrm{mol} \mathrm{RbCl}$ and 2.0, 5.0 or $10.0 \mu \mathrm{mol}$ of OA. The second group received the same amount of $\mathrm{RbCl}$ and $10^{-3} \mu \mathrm{mol}$ of ouabain per animal. The third group (controls) received only $8 \mu \mathrm{mol}$ of $\mathrm{RbCl}$. After $30 \mathrm{~min}$, the animals were sacrificed with isoflurane, and their lungs were removed, rinsed in cold PBS and cut into small pieces. After the removal of excess liquid with filter paper, $0.5 \mathrm{~g}$ of the lung tissue was transferred to glass tubes for mineralization. After $5 \mathrm{~mL}$ of $65 \%$ nitric acid was added, the tubes were heated in a digesting plate (model TE 040125 -Tecnal Ind.) until complete digestion. After cooling, the volumes were standardized at $25 \mathrm{~mL}$ using distilled water. Mineralized tissue samples were used to quantify the $\mathrm{Rb}^{+}$[14]. $\mathrm{Rb}^{+}$was quantified by inductively coupled plasma optical emission spectrometry (ICP-OES) using an Ultima 2 apparatus with Mira Mist Nebulizer and spray chamber (Jobin Yvon, Longjumeau, France). A rubidium nitrate standard (Ultra Scientific, EUA) was used to construct the calibration curve. The results were expressed in $\mu \mathrm{mol}$ of $\mathrm{Rb}^{+}$incorporated per 30 min per gram of tissue.

Total and differential cell analysis and total protein assay of bronchoalveolar lavage fluid (BALF)

Bronchoalveolar lavage was performed after the trachea was isolated by blunt dissection. A small caliber tube 
was inserted into the airway. Three volumes of $1.0 \mathrm{~mL}$ of PBS were sequentially instilled, gently aspirated and pooled. In every instillation/aspiration cycle, the same volume $(1.0 \mathrm{~mL})$ was recovered from each animal. Total leukocyte counts were performed by optical microscopy in Neubauer chambers after diluting BALF samples in Türk solution ( $2 \%$ acetic acid). Differential leukocyte counts were determined in cytocentrifuged smears stained by the May-Grunwald-Giemsa method. The BALF total protein in the supernatant was determined by the Micron BCA Kit method (Pierce) according to the manufacturer's instructions.

\section{Lipid body staining and counting}

While still moist, the leukocytes on the cytospin slides were fixed in $3.7 \%$ formaldehyde in $\mathrm{Ca}^{2}+-, \mathrm{Mg}^{2+}$ free HBSS medium ( $\mathrm{pH}$ 7.4) and stained with $1.5 \%$
$\mathrm{OsO}_{4}$, as described by Bozza [15]. Lipid bodies were enumerated by light microscopy with oil-immersion objective lens in 50 consecutively scanned leukocytes.

\section{Leukotriene $\mathrm{B}_{4}\left(\mathrm{LTB}_{4}\right)$ and Prostaglandin $\mathrm{E}_{2}\left(\mathrm{PGE}_{2}\right)$}

$\mathrm{LTB}_{4}$ and $\mathrm{PGE}_{2}$ in the BALF supernatants were assayed by EIA kits according to the manufacturer's instructions (Cayman Chemical, Ann Arbor, Mi).

\section{Morphological studies}

We euthanized the animals using a $\mathrm{CO}_{2}$ chamber 30 minutes or $24 \mathrm{~h}$ after the intravenous injection of OA, ouabain or sterile saline. The lungs were removed and then fixed in 3.7\% neutral buffered formalin, embedded in paraffin, sectioned into $4 \mu \mathrm{m}$ samples and stained with hematoxylin and eosin. Macroscopic photos were taken after the lung had been removed.

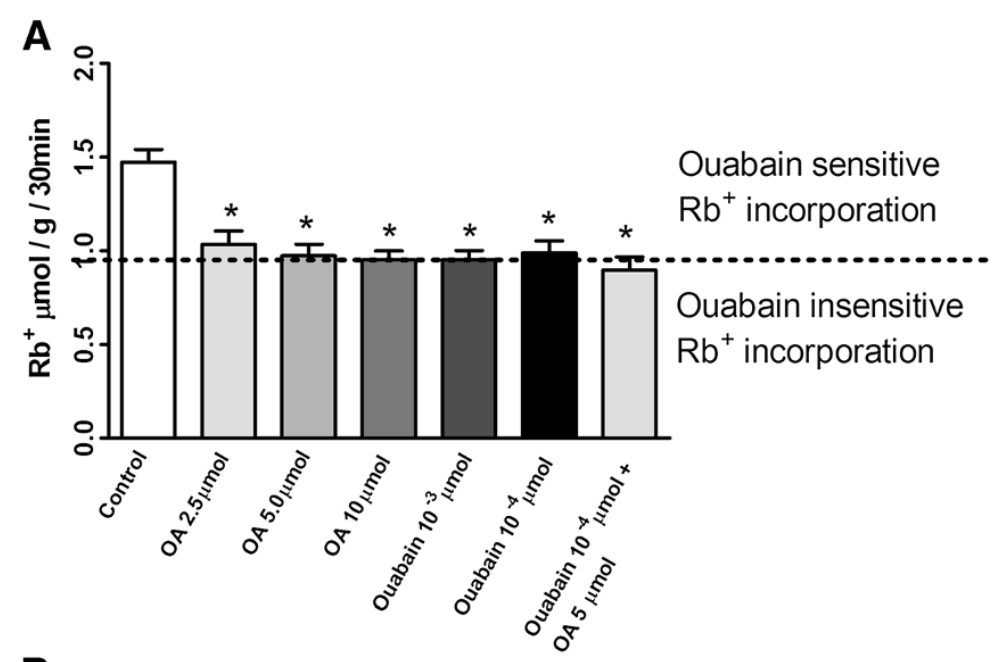

B

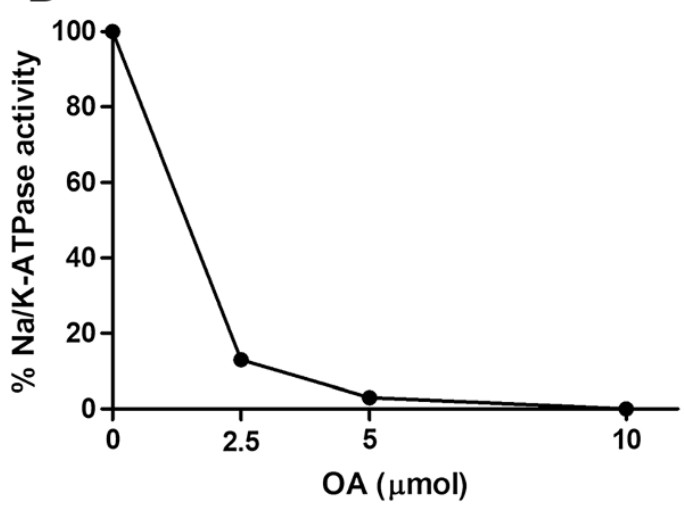

Figure 1 Inhibition of $\mathrm{Rb}^{+}$incorporation into lung tissue by $\mathrm{OA}$ and ouabain. (A) Control group was treated solely with $8 \mu \mathrm{mol} R \mathrm{Rb}^{+}$. In the experimental groups, $2.5,5$ and $10 \mu \mathrm{mol}$ of $\mathrm{OA} ; 10^{-3}$ or $10^{-4} \mu \mathrm{mol}$ of ouabain; or $10^{-4} \mu \mathrm{mol}$ ouabain plus $\mathrm{OA} 5 \mu \mathrm{mol}$ were injected by the i.v. route together with $8 \mu \mathrm{mol} \mathrm{Rb^{+ }}$. Rb ${ }^{+}$incorporation in lungs was measured after 30 min by ICP-OES in mineralized lung tissues. The results are expressed in

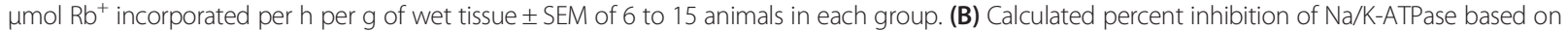
data from Figure $1 \mathrm{~A}$ (the difference between $\mathrm{Rb}^{+}$incorporation in absence and in presence of ouabain was considered as $100 \%$ enzyme activity). ${ }^{*} \mathrm{P}<0.0001$, compared to controls. 


\section{Airway function measurements}

These evaluations were performed on unrestrained animals, individually, 24 hours after the challenge by barometric plethysmography with a whole body plethysmograph (WBP, Buxco, Troy, NY), as previously described [16].

\section{Statistical analysis}

The results were expressed as the means \pm SEM and were analyzed with One-way Anova followed by the NeumanKeuls-Student test. Differences were considered significant at $\mathrm{p}<0.05$.

\section{Results}

The evaluation of the $\mathrm{Na} / \mathrm{K}$-ATPase activity in lung cells was performed by a single injection of $\mathrm{Rb}^{+}$or $\mathrm{Rb}^{+}$plus $\mathrm{OA}$ and then measuring the $\mathrm{Rb}^{+}$incorporation into the lung tissue after discounting the basal contamination obtained by inoculating $10^{-3} \mu \mathrm{mol}$ of ouabain. Figure $1 \mathrm{~A}$ shows the $\mathrm{Rb}^{+}$incorporation by the lung tissue 30 minutes after its inoculation, as well as the different doses of OA or ouabain or ouabain plus OA. Figure 1B displays the calculated $\mathrm{Na} / \mathrm{K}$-ATPase inhibition curve obtained from the data of Figure 1A. We also measured the $\mathrm{Rb}^{+}$incorporation at 6 and $24 \mathrm{~h}$ after the challenge (Figure 2). Table 1 shows the percentage of $\mathrm{Rb}^{+}$incorporation after a $10 \mu \mathrm{mol}$ OA injection. OA inhibition, either of the total amount or ouabain-sensitive $\mathrm{Rb}^{+}$incorporation, was greater at $30 \mathrm{~min}$ but remained significant until $24 \mathrm{~h}$

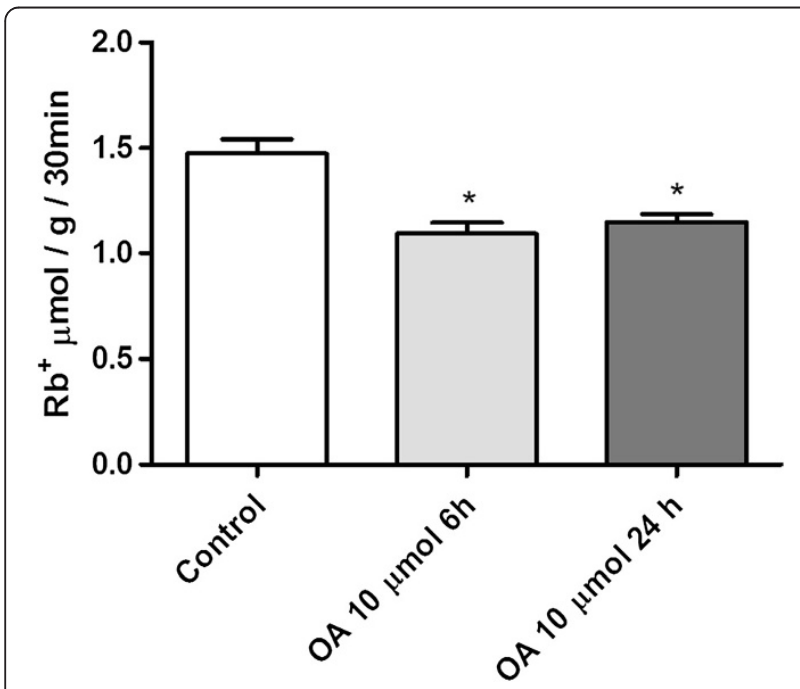

Figure 2 Inhibition of $\mathrm{Rb}^{+}$incorporation into lung tissue by $\mathrm{OA}$

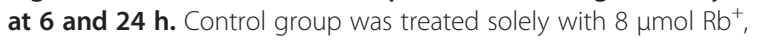
and $10 \mu \mathrm{mol}$ of OA was injected by the i.v. route. After $5 \mathrm{~h}$ and $30 \mathrm{~min}$ or $23 \mathrm{~h}$ and $30 \mathrm{~min}$, the animals were injected with $8 \mu \mathrm{mol}$ $\mathrm{Rb}^{+} . \mathrm{Rb}^{+}$incorporation in lungs was measured 6 or $24 \mathrm{~h}$ after the OA challenge by ICP-OES in mineralized lung tissues. The results are expressed in $\mu \mathrm{mol} \mathrm{Rb}^{+}$incorporated per $\mathrm{h}$ per $\mathrm{g}$ of wet tissue $\pm \mathrm{SEM}$ of 6 to 21 animals in each group.
Table 1 Inhibition of the $\mathbf{R b}^{+}$incorporation in the lung tissue and NKA inhibition by $10 \mu \mathrm{mol}$ of oleic acid

\begin{tabular}{|c|c|c|c|}
\hline \multirow[b]{2}{*}{ Parameter analyzed } & \multicolumn{3}{|c|}{$\%$ of total $\mathbf{R b}^{+}$uptake and NKA } \\
\hline & \multicolumn{3}{|c|}{ Inhibition by $10 \mu \mathrm{mol}$ of $\mathrm{OA}$} \\
\hline Time & $30 \mathrm{~min}$ & $6 \mathrm{~h}$ & $24 \mathrm{~h}$ \\
\hline Inhibition of total Rubidium uptake & $36 \%$ & $25.8 \%$ & $21 \%$ \\
\hline Ouabain-sensitive NKA inhibition $^{*}$ & $100 \%$ & $71.8 \%$ & $63.8 \%$ \\
\hline
\end{tabular}

"OA inhibited $\mathrm{Rb}^{+}$incorporation just as ouabain did $\left(10^{-3} \mu \mathrm{mol}\right)$ after $30 \mathrm{~min}$. This was considered to be total NKA inhibition.

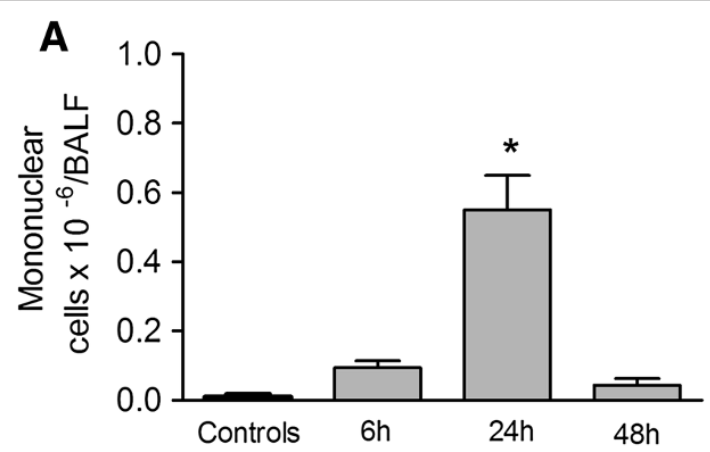

B

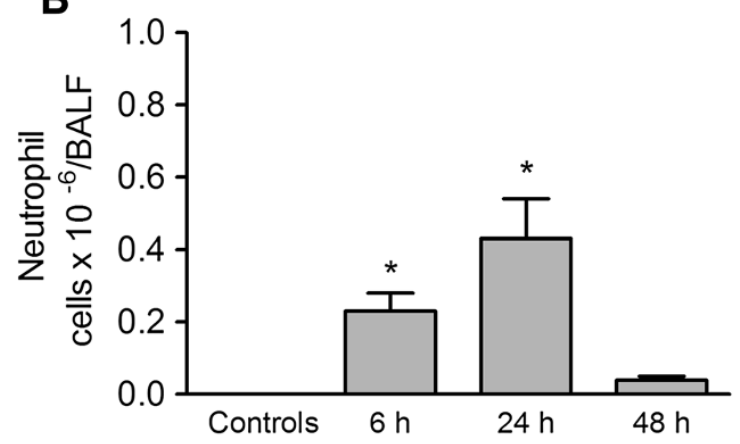

C

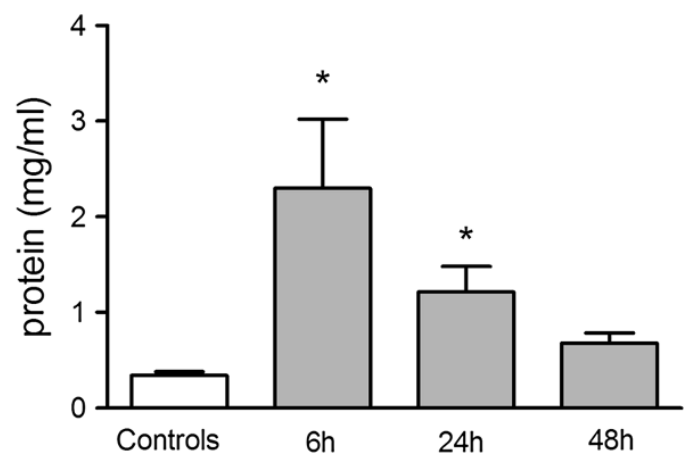

Figure 3 Cell accumulation and total protein content in BALF 6, 24 and $48 \mathrm{~h}$ after $\mathrm{OA}$ injection. Mononuclear cells (A), neutrophils (B) and total protein (C). Control group received the same volume of sterile saline. OA (dark columns) was injected i.v. at $10 \mu \mathrm{mol}$. The results are means \pm SEM from at least 3 different experiments. Each point in an experiment is the mean of 7 different animals. ${ }^{*} P<0.0001$, compared to controls. 

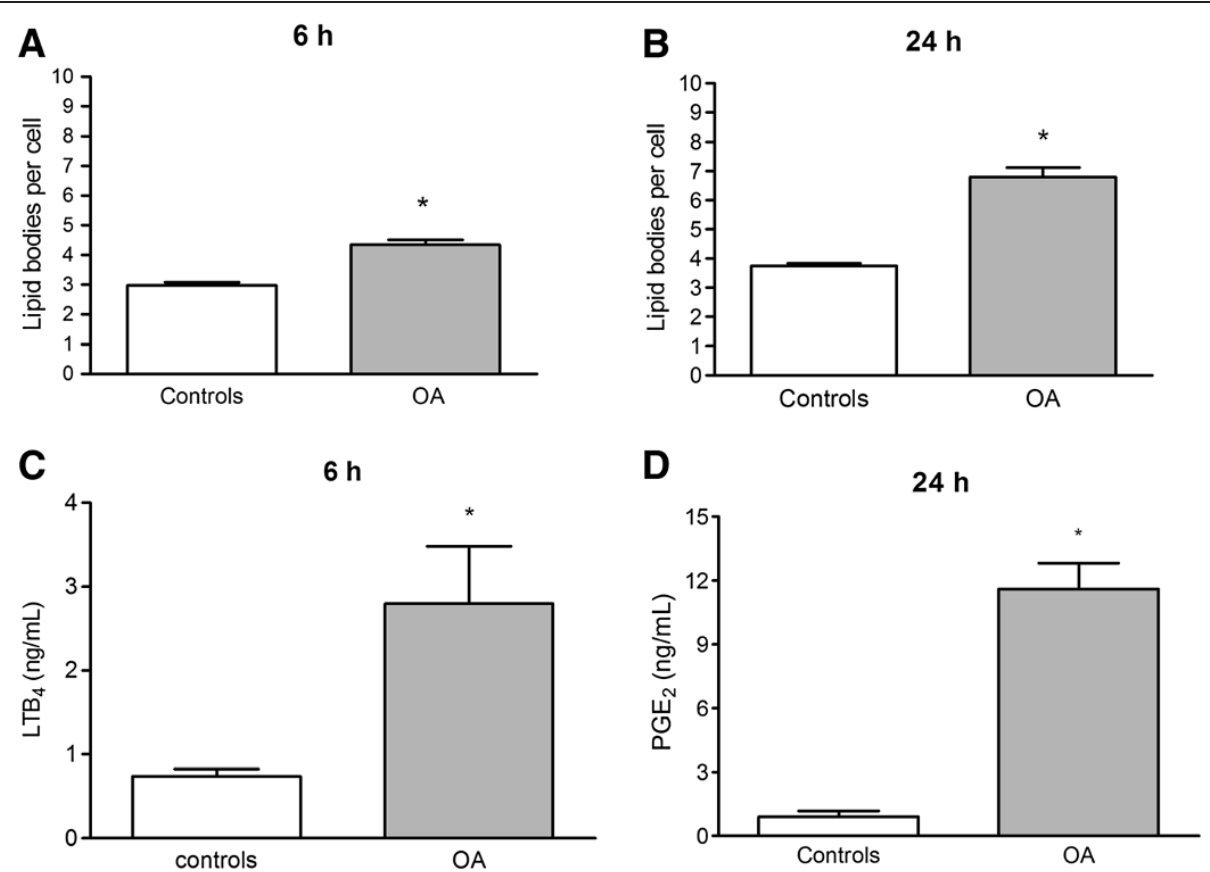

Figure 4 Lipid body formation in leukocytes and leukotriene $B_{4}$ and $\mathrm{PGE}_{2}$ production in BALF of OA treated mice. Animals received $10 \mu \mathrm{mol} O \mathrm{OA}$ by i.v. injection (dark columns). Lipid bodies at $6 \mathrm{~h}$ (A) and $24 \mathrm{~h}$ (B) after the OA injection were enumerated in 50 consecutive cells in osmium-stained cytocentrifuged smears; $\mathrm{LTB}_{4}$ (C) at $6 \mathrm{~h}$ and $\mathrm{PGE}_{2}$ (D) at $24 \mathrm{~h}$ after OA challenge were determined in the BALF by ELISA. The control group received sterile saline. The results are means \pm SEM of 6 animals in each group. ${ }^{*} P<0.001$, compared to controls.

The onset of ARDS after a $10 \mu \mathrm{mol}$ OA intravenous injection was characterized by measurements of protein extravasation, leucocyte migration, lipid body formation in leucocytes and $\mathrm{PGE}_{2}$ and $\mathrm{LTB}_{4}$ production, which were used as markers of lung edema and inflammation in BALF samples. Increased cell migration was detected after 6 hours, but a higher neutrophil infiltration occurred at $24 \mathrm{~h}$ after $\mathrm{OA}$ administration, returning to basal levels at $48 \mathrm{~h}$ (Figures $3 \mathrm{~A}$ and 3B). Lung edema formation, which was evaluated by assaying the total proteins in the BALF supernatants, occurred as early as $6 \mathrm{~h}$ but was less intense at $24 \mathrm{~h}$ before returning to basal levels at $48 \mathrm{~h}$ (Figure $3 \mathrm{C}$ ).

Lipid bodies produce lipid mediators that can be used as markers of cell activation. These markers increased at $6 \mathrm{~h}$ and reached a peak at $24 \mathrm{~h}$ after the OA treatment (Figure 4A and 4B). The lipid mediator $\mathrm{LTB}_{4}$ was elevated at $6 \mathrm{~h}$ (Figure $4 \mathrm{C}$ ), while $\mathrm{PGE}_{2}$ was markedly augmented $24 \mathrm{~h}$ after OA treatment (Figure 4D).

As edema formation is a characteristic of ARDS, we also measured the protein content in BALF after different doses of ouabain and ouabain plus OA in $24 \mathrm{~h}$ (Figure 5). All doses tested caused an increase in the total protein in the BALF, but they did not induce cell accumulation in the BALF at this time point.

Macroscopic examination of mice lungs injected with ouabain or $\mathrm{OA}$ revealed congestion and hemorrhagic areas at $30 \mathrm{~min}$ (Figure 6) that were also detected at

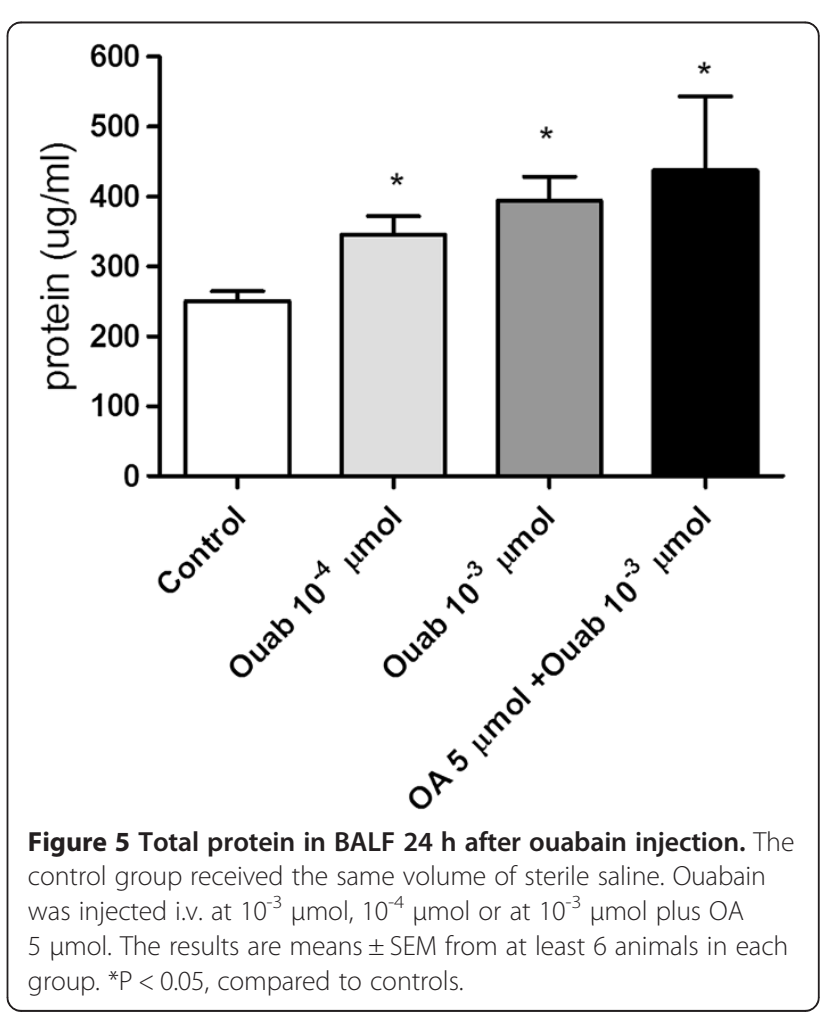



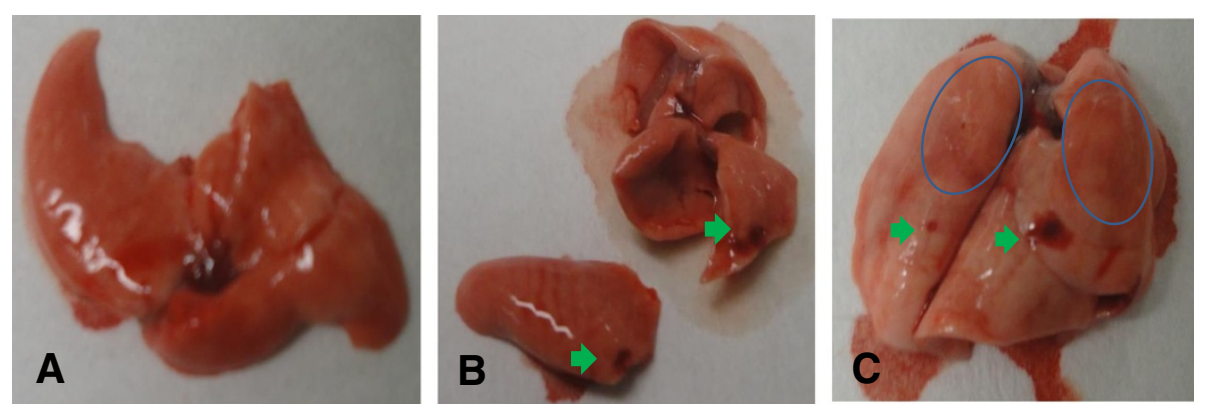

Figure 6 Illustrative macroscopic examination of lungs after OA or ouabain challenge. Macroscopic photos of mice lungs challenged with sterile saline (A) ouabain $10^{-3} \mathrm{\mu mol} /(\mathbf{B})$, or OA $10 \mu \mathrm{mol}$ (C). Green arrows point to hemorrhagic points, and blue circles delimitate large hemorrhagic areas.

$24 \mathrm{~h}$ (not shown). In addition, we performed histological examinations of the lungs $30 \mathrm{~min}$ and $24 \mathrm{~h}$ after the challenge with OA, ouabain or ouabain plus OA. To quantify the extent of the lung injury, we adapted a scoring system that takes into account intra-alveolar hemorrhage, leukocyte infiltration and tissue disruption [17]. Table 2 demonstrates that OA and ouabain significantly increased lung injury scores, although the effect was more pronounced with OA. The administration of OA plus ouabain did not have an additive effect because the lung injury scores were similar to the ones observed with OA alone. These results are illustrated in Figures 7 and Figure 8 for the $30 \mathrm{~min}$ and $24 \mathrm{~h}$ time point analysis, respectively. Hemorrhagic points, leukocytes in the lung tissue and some tissue disruption can be clearly detected after OA or ouabain injury, but, as mentioned above, the effect was more pronounced in the OAchallenged mice. Lung function was also evaluated by whole body plethysmography $30 \mathrm{~min}$ after OA or ouabain. Compared to controls, both OA and ouabain mice had significantly increased enhanced breathing pauses (Penh), which was used as an index of airway obstruction (from $0.58 \pm 0.69$ in controls to $1.25 \pm 0.34$ in ouabain-injected mice and $0.87 \pm 0.12$ in OA-injected mice).

\section{Discussion}

The doses of oleic acid inhibited $\mathrm{Rb}^{+}$uptake by the lung tissue, as did the $10^{-3} \mu \mathrm{mol}$ dose of ouabain, a classical $\mathrm{Na} / \mathrm{K}$-ATPase inhibitor. We assume that this ouabain dose completely blocked the rubidium incorporation associated with the $\mathrm{Na} / \mathrm{K}$-ATPase activity because higher doses killed the majority of the animals. Lower ouabain doses or ouabain plus OA had similar effects on $\mathrm{Rb}^{+}$tissue incorporation. The somewhat high ouabain-insensitive $\mathrm{Rb}^{+}$measurement can be attributed not only to an incomplete tissue-washing procedure but also to a passive $\mathrm{Rb}^{+}$ incorporation through $\mathrm{K}^{+}$channels. The proposed in vivo $\mathrm{Na} / \mathrm{K}$-ATPase assay has low costs and high reliability and represents an adaptation of the mouse lung assessment method of our previous report, which measured liver $\mathrm{Na} / \mathrm{K}$-ATPase activity through a liver perfusion methodology in rats [14].

We chose a model of OA-induced ARDS in mice because the mouse is an extensively used model that remains relevant in the study of lung injury mechanisms. Moreover, inflammation induced by the intravenous administration of OA resembles ARDS in many morphological, histological and physiological aspects [18]. In this regard, ARDS patients or at-risk patients who subsequently develop ARDS have increased plasma OA concentrations [19]. Sepsis patients could develop ARDS [20], as they also present markedly increased plasma OA levels compared to healthy volunteers [21]. Previous work has shown that $\mathrm{OA}$ is an endogenous $\mathrm{Na} / \mathrm{K}-\mathrm{ATPase}$ inhibitor [22]. Furthermore, OA was able to inhibit $\mathrm{Na} / \mathrm{K}$-ATPase in an ARDS rabbit model, resulting in a significantly increased endothelial permeability [23,24]. In most ARDS patients, the edema resolution and $\mathrm{Na}, \mathrm{K}-\mathrm{ATP}$ ase activity are impaired and only patients with reduced edema clearance have a higher mortality $[8,25,26]$ suggesting that $\mathrm{Na}$, K-ATPase is an important player in the pathophysiology of ARDS.

Leukocyte recruitment is essential to the immune response to an injury or an infection [27]. In ARDS,

Table 2 Lung injury score extension based on histological analysis

\begin{tabular}{lccccc}
\hline & Control & Ouabain $\mathbf{1 0}^{-4} \boldsymbol{\mu m o l}$ & Ouabain $\mathbf{1 0 ^ { - 3 }} \boldsymbol{\mu m o l}$ & OA & OA + Ouabain $10^{-3} \boldsymbol{\mu m o l}$ \\
\hline *Lung injury score $30 \mathrm{~min}$ & - & + & ++ & ++++ & ++++ \\
*Lung injury score $24 \mathrm{~h}$ & - & + & + & +++ & +++ \\
\hline
\end{tabular}

* Lung injury scores take into account the intra-alveolar hemorrhage, leukocyte infiltration and tissue disruption. The symbol - represents areas without dysfunction and the symbols + to +++++ represent mild to severe lung injury. 


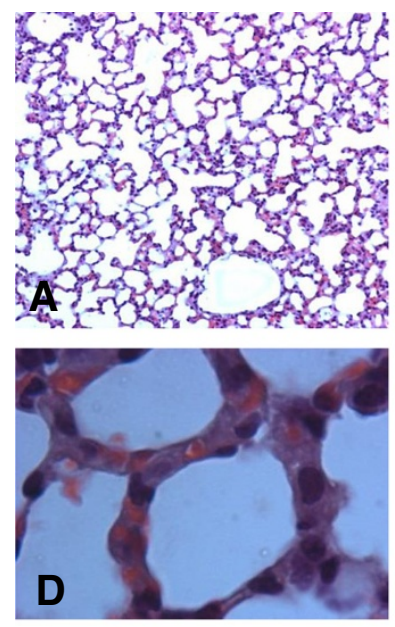

Sterile saline

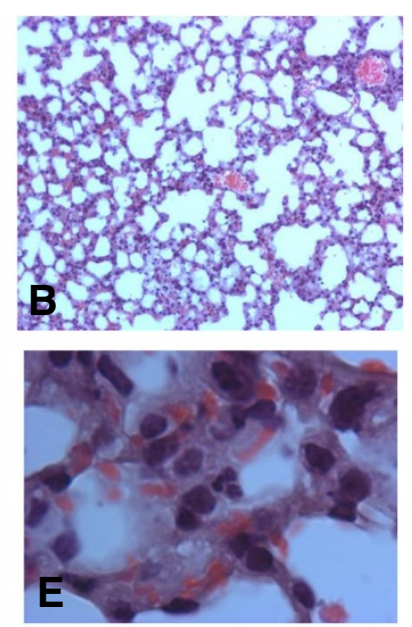

Ouabain $10^{-4} \mu \mathrm{mol}$
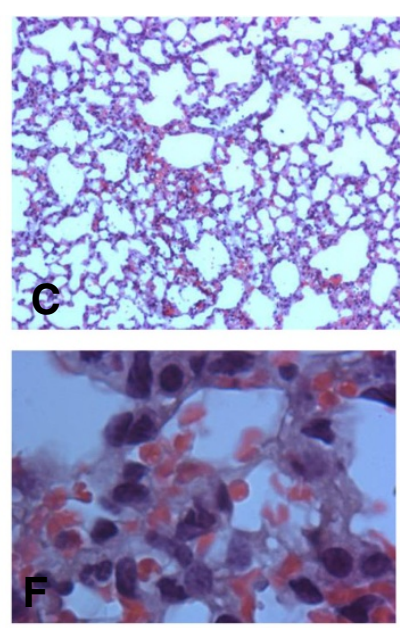

Ouabain $10^{-3} \mu \mathrm{mol}$
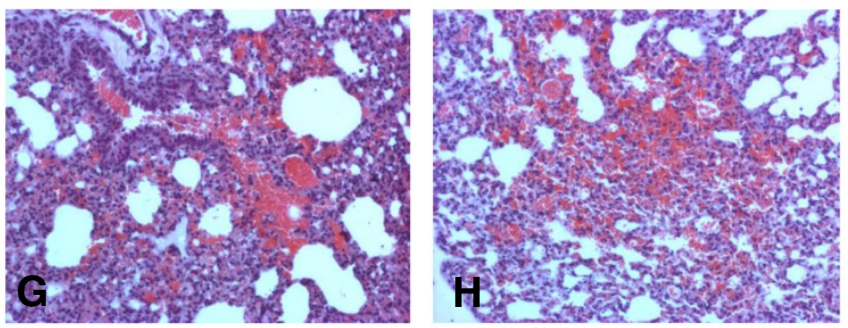

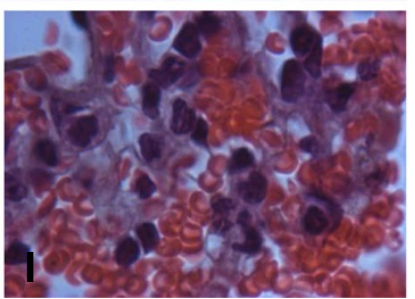

OA $10 \mu \mathrm{mol}$

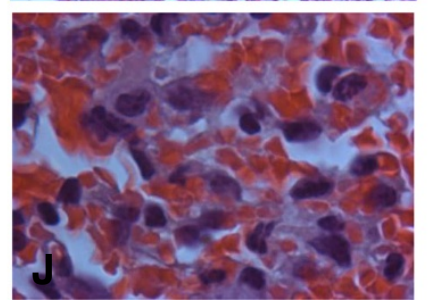

OA $10 \mu \mathrm{mol}+$ ouabain $10^{-3}$ $\mu \mathrm{mol}$

Figure 7 Illustrative microphotographs of lung pathology caused by $O A$ and ouabain at $\mathbf{3 0}$ min. Sterile saline (control - A, D); Ouabain $\left.10^{-4} \mathbf{( B ,} \mathbf{E}\right)$, or $10^{-3} \mu \mathrm{mol}(\mathbf{C}, \mathbf{F})$; OA $10 \mu \mathrm{mol}(\mathbf{G}, \mathbf{I})$ or OA $10 \mu \mathrm{mol}+$ ouabain $10^{-3} \mu \mathrm{mol}(\mathbf{H}, \mathbf{J})$ were injected i.v. 30 min before the collection of the lungs. Figures are shown at $100 \times$ magnification $(\mathbf{A}, \mathbf{B}, \mathbf{C}, \mathbf{G}, \mathbf{H})$ or $1000 \times$ magnification $(\mathbf{D}, \mathbf{E}, \mathbf{F}, \mathbf{I}, \mathbf{J})$. These pictures are representative of at least 5 animals in each group.

neutrophils are the main cells migrating to lungs [28]. Activated neutrophils release an arsenal of potent molecules and contribute to increased tissue damage and inflammation [29]. Whether neutrophil infiltration is the cause or the consequence of the injury is still debatable because ARDS may develop in patients with neutropenia [5]. We detected an increase in total cell accumulation in the BALF (mainly neutrophils), which was consistent with an ARDS type of reaction induced by OA.

Lipid bodies are cytoplasmic inclusions that are present in different cellular types [30]; they increase in number and size in cells involved in inflammatory and immunologic processes [31]. In our experiments, oleic acid induced lipid body formation in leukocytes, denoting cellular activation [32]. These structures are rich in enzymes and substrates, generating lipid mediators such as $\mathrm{LTB}_{4}$ (a potent chemotactic agent to neutrophils) and $\mathrm{PGE}_{2}$ [15], inducing cell migration and increasing endothelial permeability. It has already been described that OA-induced ALI increased plasma $\mathrm{PGE}_{2}$ levels [33]. The crosstalk of intracellular pathways with lipid body formation could stem from OA signaling, including inflammasome activation by the low intracellular concentration of $\mathrm{K}^{+}$due to pump inhibition [34]. However, this activation could also involve the role of this enzyme in other signal transduction pathways [35]. Leukotrienes, including $\mathrm{LTB}_{4}$, were not likely to be relevant mediators involved in pathophysiology of acute lung injury induced by oleic acid in 


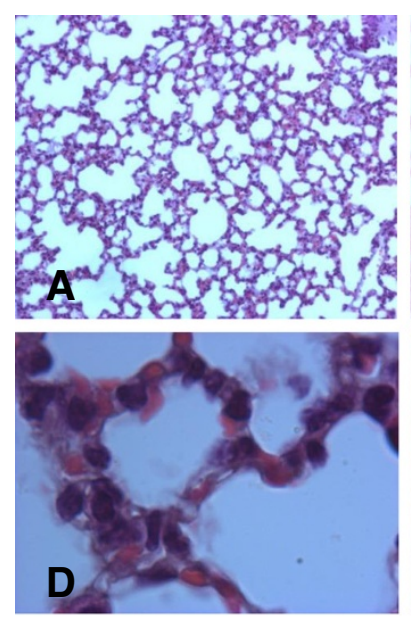

Sterile saline

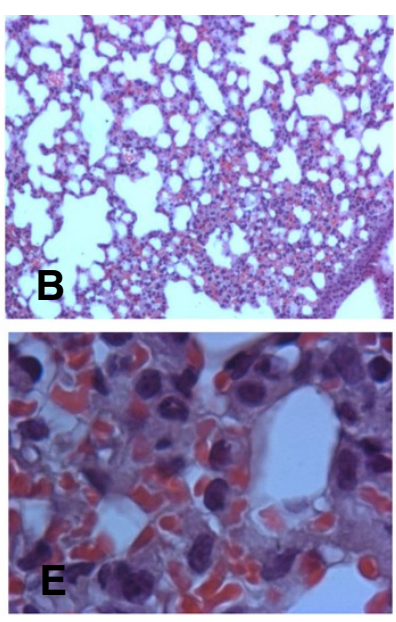

Ouabain $10^{-4} \mu \mathrm{mol}$

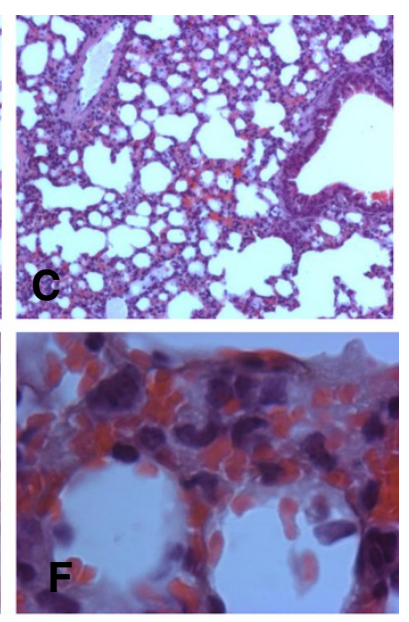

Ouabain $10^{-3} \mu \mathrm{mol}$
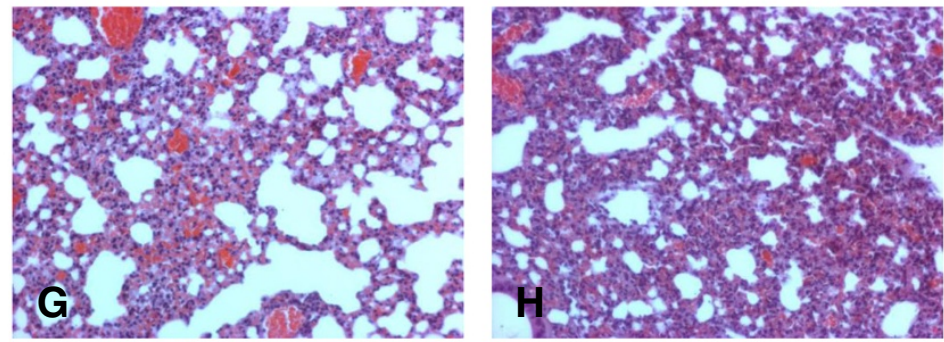

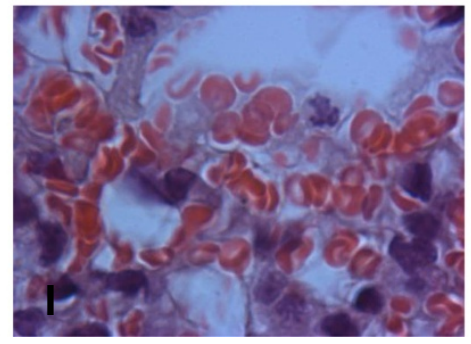

OA $10 \mu \mathrm{mol}$

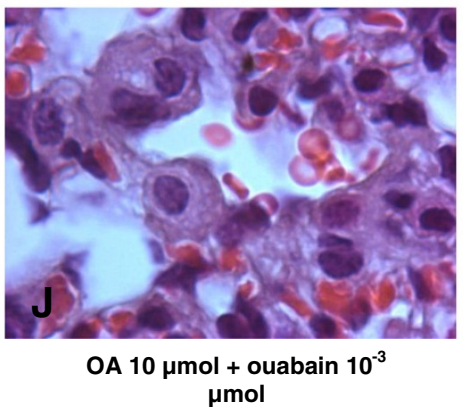

Figure 8 Illustrative microphotographs of lung pathology caused by OA and ouabain at $24 \mathrm{~h}$. Sterile saline (control $-\mathbf{A}, \mathrm{D}) ;$ ouabain $10^{-4}$ (B, E), or $10^{-3} \mu \mathrm{mol}(\mathbf{C}, \mathbf{F})$; OA $10 \mu \mathrm{mol}(\mathbf{G}, \mathbf{I})$ or OA $10 \mu \mathrm{mol}+$ ouabain $10^{-3} \mu \mathrm{mol}(\mathbf{H}, \mathbf{J})$ were injected i.v. $24 \mathrm{~h}$ before the collection of the lungs. Figures are shown at $100 \times$ magnification $(\mathbf{A}, \mathbf{B}, \mathbf{C}, \mathbf{G}, \mathbf{H})$ or $1000 \times$ magnification $(\mathbf{D}, \mathbf{E}, \mathbf{F}, \mathbf{I}, \mathbf{J})$. These pictures are representative of at least 5 animals in each group.

pigs [36]. We showed that the increase in $\mathrm{BALF} \mathrm{LTB}_{4}$ was similar to the increase observed in rats [37]. These observations might indicate the existence of species-specific effects of OA. Importantly, the rise of $\mathrm{LTB}_{4}$ and $\mathrm{PGE}_{2}$ in human samples preceded ARDS in injured blunt-trauma patients [38]. Similarly, in our model, OA augmented BALF $\mathrm{PGE}_{2}$, suggesting that it is suited for comparison with the clinical situation.

Oleic acid-induced $\mathrm{Na} / \mathrm{K}$-ATPase inhibition persists until $24 \mathrm{~h}$ after the challenge, suggesting that this mechanism may be an important contributor to lung injury. The fact that ouabain-induced lung injury was similar to that induced by $\mathrm{OA}$, but less severe, may indicate that OA has additional mechanisms of injury beyond the inhibition of the $\mathrm{Na} / \mathrm{K}$ ATPAse. As the $\mathrm{Na} / \mathrm{K}$-ATPase is the sole biological target known for ouabain, this observation reinforces the claim that OA may have additional biological targets contributing to lung injury, as discussed above. Nevertheless, lung injury demonstrates a nice correlation with $\mathrm{Na} / \mathrm{K}$-ATPase inhibition, both at $30 \mathrm{~min}$ and $24 \mathrm{~h}$ after the challenge, suggesting a potential causal effect. that oleic acid can cause lung injury with alveoli disruption has been well characterized in animal models [39] and may contribute to the lower $\mathrm{Rb}^{+}$ 
uptake by the lung tissue. Here, the tissue damage was observed macroscopically, and we demonstrated functional repercussions with either ouabain or OA.

As a corollary, patients with high levels of plasma OA have a higher risk of developing ARDS [19] or showing deleterious effects on their heart muscle [40]. Therefore, we can suggest that lowering OA plasma levels could help in the prevention of the high mortality and morbidity of ARDS.

\section{Conclusion}

In conclusion, we developed a new, non-radioactive assay to quantify $\mathrm{Na} / \mathrm{K}$-ATPase in vivo. The inhibition of the $\mathrm{Na} / \mathrm{K}$-ATPase in vivo by either OA- or ouabain-induced lung injury in mice. Our data reinforce the idea that $\mathrm{Na} / \mathrm{K}$-ATPase inhibition by OA seems to play a relevant role in lung injury during conditions of high plasma OA levels, such sepsis, leptospirosis, pancreatitis and eclampsia.

\section{Abbreviations}

ARDS: Acute respiratory distress syndrome; Na/K-ATPase: Sodium potassium ATPase pump; OA: Oleic acid (18:1n-9); ICP-OES: Coupled plasma-optical emission spectrometry; ENaC: Epithelial apically located sodium channel; LAL: Limulus amebocyte lysate test; BALF: Bronchoalveolar lavage fluid.

\section{Competing interests}

The authors state that they have no conflicts of interest to disclose.

\section{Authors' contributions}

CFGA - Conception and design of the experiments; participation in the manuscript drafting and direct participation in the experiments. PB Performance of the $\mathrm{Na} / \mathrm{K}$-ATPase experiments based on $\mathrm{Rb}^{+}$incorporation. ARS - Performance of the animal manipulations and aid in drafting the manuscript. IMMM and FMJO - Participation in the animal experiments. PTB - In charge of the lipid bodies and of the design of the lipid mediator experiments. RES and ASF - Performance of data acquisition and analysis of the $\mathrm{Na} / \mathrm{K}$-ATPase results on $\mathrm{Rb}^{+}$incorporation. MYI - Participation in the experimental design and in manuscript drafting. HCCFN-Conception of the study, participation in its design and aid in drafting the manuscript. MVCFParticipation in the manuscript drafting and approval of the final version of the manuscript. All authors read and approved the final manuscript.

\section{Acknowledgements}

This work received financial support from Fundação de Amparo a Pesquisa do Estado do Rio de Janeiro (FAPERJ), Programa Estratégico de Apoio à Pesquisa em Saúde (PAPES)-FIOCRUZ and Conselho Nacional de Desenvolvimento Científico e Tecnológico (CNPq). We acknowledge the institutions where this work was accomplished, as follows: Fundação Oswaldo Cruz (FIOCRUZ), Universidade do Estado do Rio de Janeiro (UERJ) and Universidade Federal Fluminense (UFF).

\section{Author details}

${ }^{1}$ Instituto Oswaldo Cruz, Laboratório de Imunofarmacologia, Fiocruz, Rio de Janeiro, RJ, Brazil. ${ }^{2}$ Departamento de Biologia Celular e Molecular, Instituto de Biologia, Universidade Federal Fluminense, Niterói, RJ, Brazil. ${ }^{3}$ Departamento de Química Analítica, Universidade Federal do Rio de Janeiro, Rio de Janeiro, RJ, Brazil. ${ }^{4}$ Departamento de Medicina Interna, Faculdade de Ciências Médicas, Universidade do Estado do Rio de Janeiro, Rio de Janeiro, RJ, Brazil.

Received: 8 October 2012 Accepted: 28 October 2013

Published: 31 October 2013

\section{References}

1. Ashbaugh DG, Bigelow DB, Petty $T L$, Levine BE: Acute respiratory distress in adults. Lancet 1967, 2:319-323

2. Wang HM, Bodenstein M, Markstaller K: Overview of the pathology of three widely used animal models of acute lung injury. Eur Surg Res 2008, 40:305-316.

3. Ranieri VM, Rubenfeld GD, Thompson BT, Ferguson ND, Caldwell E, Fan E, Camporota L, Slutsky AS: Acute respiratory distress syndrome: the Berlin definition. JAMA 2012, 307:2526-2533

4. Costa EL, Amato MB: The new definition for acute lung injury and acute respiratory distress syndrome: is there room for improvement? Curr Opin Crit Care 2013, 19:16-23.

5. Ware LB, Matthay MA: The acute respiratory distress syndrome. N Eng/ J Med 2000, 342:1334-1349.

6. Pierrakos C, Karanikolas M, Scolletta S, Karamouzos K, Velissaris D: Acute respiratory distress syndrome: pathophysiology and therapeutic options. J Clin Med Res 2012, 4:7-16.

7. Neamu RF, Martin GS: Fluid management in acute respiratory distress syndrome. Curr Opin Crit Care 2013, 19:24-30.

8. Sznajder Jl, Factor $P$, Ingbar DH: Invited review: lung edema clearance:

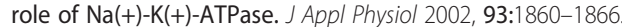

9. Vadasz I, Morty RE, Olschewski A, Konigshoff M, Kohstall MG, Ghofrani HA, Grimminger F, Seeger W: Thrombin impairs alveolar fluid clearance by promoting endocytosis of $\mathrm{Na}+, \mathrm{K}+-$ ATPase. Am J Respir Cell Mol Biol 2005, 33:343-354.

10. Matthay MA, Folkesson $\mathrm{HG}$, Clerici C: Lung epithelial fluid transport and the resolution of pulmonary edema. Physio/ Rev 2002, 82:569-600.

11. Matthay MA, Zimmerman GA: Acute lung injury and the acute respiratory distress syndrome: four decades of inquiry into pathogenesis and rational management. Am J Respir Cell Mol Biol 2005, 33:319-327.

12. Ballard-Croft C, Wang D, Sumpter $L R$, Zhou X, Zwischenberger JB: Large-animal models of acute respiratory distress syndrome. Ann Thorac Surg 2012, 93:1331-1339.

13. de Albuquerque CF G, Burth P, Younes Ibrahim M, Garcia DG, Bozza PT, Castro Faria Neto HC, Castro Faria MV: Reduced plasma nonesterified fatty acid levels and the advent of an acute lung injury in mice after intravenous or enteral oleic acid administration. Mediators Inflamm 2012 2012:601032.

14. Dos Santos MC, Burth P, Younes-lbrahim M, Goncalves CF, Santelli RE, Oliveira EP, de Castro Faria MV: Na/K-ATPase assay in the intact guinea pig liver submitted to in situ perfusion. Anal Biochem 2009, 385:65-68.

15. Bozza PT, Payne JL, Morham SG, Langenbach R, Smithies O, Weller PF: Leukocyte lipid body formation and eicosanoid generation: cyclooxygenase-independent inhibition by aspirin. Proc Natl Acad Sci USA 1996, 93:11091-11096.

16. Hamelmann E, Schwarze J, Takeda K, Oshiba A, Larsen GL, Irvin CG, Gelfand EW: Noninvasive measurement of airway responsiveness in allergic mice using barometric plethysmography. Am J Respir Crit Care Med 1997, 156:766-775.

17. Murao $Y$, Loomis W, Wolf $P$, Hoyt DB, Junger WG: Effect of dose of hypertonic saline on its potential to prevent lung tissue damage in a mouse model of hemorrhagic shock. Shock 2003, 20:29-34.

18. Shuster DP: ARDS: clinical lessons from the oleic acid model of acute injury. Am J Respir Crit Care Med 1994, 149:245-260.

19. Quinlan GJ, Lamb NJ, Evans TW, Gutteridge JM: Plasma fatty acid changes and increased lipid peroxidation in patients with adult respiratory distress syndrome. Crit Care Med 1996, 24:241-246.

20. Matthay MA, Ware LB, Zimmerman GA: The acute respiratory distress syndrome. J Clin Invest 2012, 122:2731-2740.

21. Mayer K, Gokorsch S, Fegbeutel C, Hattar K, Rosseau S, Walmrath D, Seeger W Grimminger F: Parenteral nutrition with fish oil modulates cytokine response in patients with sepsis. Am J Respir Crit Care Med 2003, 167:1321-1328.

22. Tamura M, Kuwano $H$, Kinoshita $T$, Inagami T: Identification of linoleic and oleic acids as endogenous $\mathrm{Na}+, \mathrm{K}+-$ ATPase inhibitors from acute volume-expanded hog plasma. J Biol Chem 1985, 260:9672-9677.

23. Vadasz I, Morty RE, Kohstall MG, Olschewski A, Grimminger F, Seeger W, Ghofrani HA: Oleic acid inhibits alveolar fluid reabsorption: a role in acute respiratory distress syndrome? Am J Respir Crit Care Med 2005, 171:469-479. 
24. Vadasz I, Raviv S, Sznajder Jl: Alveolar epithelium and Na, K-ATPase in acute lung injury. Intensive Care Med 2007, 33:1243-1251.

25. Sznajder J: Alveolar edema must be cleared for the acute respiratory distress syndrome patient to survive. Am J Respir Crit Care Med 2001, 163:1293-1294.

26. Ware LB, Matthay MA: Alveolar fluid clearance is impaired in the majority of patients with acute lung injury and the acute respiratory distress syndrome. Am J Respir Crit Care Med 2001, 163:1376-1383.

27. Kelly $M$, Hwang $J M$, Kubes $P$ : Modulating leukocyte recruitment in inflammation. J Allergy Clin Immunol 2007, 120:3-10.

28. Chen DL, Schuster DP: Positron emission tomography with [18 F] fluorodeoxyglucose to evaluate neutrophil kinetics during acute lung injury. Am J Physiol Lung Cell Mol Physiol 2004, 286:L834-L840.

29. Maniatis NA, Kotanidou A, Catravas JD, Orfanos SE: Endothelial pathomechanisms in acute lung injury. Vascul Pharmacol 2008, 49:119-133.

30. Dvorak AM, Morgan E, Schleimer RP, Ryeom SW, Lichtenstein LM, Weller PF: Ultrastructural immunogold localization of prostaglandin endoperoxide synthase (cyclooxygenase) to non-membrane-bound cytoplasmic lipid bodies in human lung mast cells, alveolar macrophages, type II pneumocytes, and neutrophils. J Histochem Cytochem 1992, 40:759-769.

31. Bozza PT, Magalhaes KG, Weller PF: Leukocyte lipid bodies - Biogenesis and functions in inflammation. Biochim Biophys Acta 2009, 1791:540-551.

32. Bozza PT, Yu W, Penrose JF, Morgan ES, Dvorak AM, Weller PF: Eosinophil lipid bodies: specific, inducible intracellular sites for enhanced eicosanoid formation. J Exp Med 1997, 186:909-920.

33. Hageman JR, McCulloch K, Hunt CE, Cobb M, Quade B, Crussi F, Pachman L: Oleic acid lung injury increases plasma prostaglandin levels. Prostaglandins Leukot Essent Fatty Acids 1989, 35:157-164.

34. Lacroix-Lamande S, D'Andon MF, Michel E, Ratet G, Philpott DJ, Girardin SE, Boneca IG, Vandewalle A, Werts C: Downregulation of the Na/K-ATPase pump by leptospiral glycolipoprotein activates the NLRP3 inflammasome. J Immunol 2012, 188:2805-2814.

35. Mijatovic T, Van Quaquebeke E, Delest B, Debeir O, Darro F, Kiss R: Cardiotonic steroids on the road to anti-cancer therapy. Biochim Biophys Acta 2007, 1776:32-57.

36. Kruse-Elliott K, Olson NC: Role of leukotrienes during oleic acid-induced lung injury in pigs. J Appl Physiol 1990, 68:1360-1367.

37. Ball HA, Cook JA, Spicer KM, Wise WC, Halushka PV: Essential fatty acid-deficient rats are resistant to oleic acid-induced pulmonary injury. J Appl Physiol 1989, 67:811-816

38. Rivkind Al, Siegel JH, Guadalupi P, Littleton M: Sequential patterns of eicosanoid, platelet, and neutrophil interactions in the evolution of the fulminant post-traumatic adult respiratory distress syndrome. Ann Surg 1989, 210:355-372. discussion 372-353.

39. Sun Y, Yang R, Zhong JG, Fang F, Jiang JJ, Liu MY, Lu J: Aerosolised surfactant generated by a novel noninvasive apparatus reduced acute lung injury in rats. Crit Care 2009, 13:R31.

40. Nogueira AC, Kawabata V, Biselli P, Lins MH, Valeri C, Seckler M, Hoshino W Junior LG, Bernik MM, de Andrade Machado JB, et al: Changes in plasma free fatty acid levels in septic patients are associated with cardiac damage and reduction in heart rate variability. Shock 2008, 29:342-348.

\section{doi:10.1186/1476-9255-10-34}

Cite this article as: Gonçalves-de-Albuquerque et al: Oleic acid inhibits lung $\mathrm{Na} / \mathrm{K}$-ATPase in mice and induces injury with lipid body formation in leukocytes and eicosanoid production. Journal of Inflammation 2013 10:34.

\section{Submit your next manuscript to BioMed Central and take full advantage of:}

- Convenient online submission

- Thorough peer review

- No space constraints or color figure charges

- Immediate publication on acceptance

- Inclusion in PubMed, CAS, Scopus and Google Scholar

- Research which is freely available for redistribution 